\title{
49. GENESIS OF THE TETHYS AND THE MEDITERRANEAN
}

\author{
Kenneth J. Hsü, Geologisches Institut, ETH Zürich, Switzerland \\ and \\ Daniel Bernoulli, Geologisch-Paläontologisches Institut, Universität Basel, Switzerland
}

\begin{abstract}
The Triassic Paleotethys was a wedge-like ocean opening to the east, which was totally eliminated during the early Mesozoic by subduction along the Cimmerian and Indosinian suture zone. The Tethys, s.s., was an Early Jurassic creation formed when Africa moved east relative to Europe. The sinistral movement of Africa continued until Late Cretaceous when the movement became dextral. The closing of the gap between Africa and Europe led to the Alpine orogeny and the elimination of much of the Tethys. Only the eastern Mediterranean Ionian and Levantine basins are left as possible relics of this Mesozoic ocean. The western Mediterranean and the Aegean are post-orogenic basins. The Balearic Basin was created during late Oligocene or earliest Miocene time by rifting tectonics. The Tyrrhenian Basin was probably somewhat younger. The presence of oceanic tholeiites under its abyssal plain indicates that submarine basalt volcanism played a major role in the genesis of this basin. The Aegean Basin is probably the youngest and has undergone considerable Pliocene-Quaternary subsidence.

Tectonic synthesis indicates that the Mediterranean basins, except perhaps the Aegean, were in existence and deep prior to the Messinian Salinity Crisis.
\end{abstract}

\section{FOREWORD}

Several attempts have been made to reconstruct the tectonic history of the Tethys and its descendent, the present-day Mediterranean (e.g., Smith, 1971; Hsü, 1971; Dewey et al., 1973; Laubscher, 1975). Differences in opinion are unavoidable. This paper is our cooperative effort to present somewhat different views. We shall emphasize some of the salient features, but pass over controversial reconstructions of the movements of continental fragments of micro-continents. This is not an objective review, but a brief summary of the views of two individuals who use the basic tenets of the plate-tectonic theory to interpret the origin and evolution of the Tethys and the Mediterranean. Details of our interpretation are presented in Hsü, in press; and Laubscher and Bernoulli in press.

\section{PALEOTETHYS}

The idea of an ancient Mediterranean was first proposed by Melchior Neumayr in 1885 . On the basis of distribution of Jurassic faunas, he postulated the existence of an equatorial ocean which extended from India in the east to Central America in the west, and separated the Neoarctic continent to the north and the Brazilian-Ethiopian continent to the south. This central mediterranean was later baptized Tethys by Eduard Suess $(1839,1901)$; he described Tethys as a Mesozoic sea north of the Gondwanaland. The mythical conti- nent Gondwana was the home of the late Paleozoic Glossopteria flora. Its inclusion in the definition of Tethys seemed to imply the existence of this mediterranean during the Paleozoic. In fact, Du Toit (1937; p. 40) referred to Tethys as an east-west trending, intercontinental ocean, separating two super-continentsLaurasia in the north and Gondwana in the south"from at least the mid-Paleozoic onwards." However, this concept of double landmasses was radically different from the single Pangea pictured by Wegener (1929), whose reconstruction did not leave room for an equatorial ocean. A more accurate reconstruction of Pangea was made by Carey in 1958, who showed that a wedge-shaped Tethys must have existed between Eurasia and the southern continents. The least-square fit of the 500-meter contour of the continents refined Carey's reconstruction (see Bullard et al., 1965; Smith, 1971). Whether or not the continents were joined during the Permian is not certain. By the end of the Triassic, at any rate, the supercontinent Pangea should have had the shape as shown by Figure 1 (Smith, 1971; Smith et al., 1973). The Tethys was then a wedge-shaped ocean opening to the east. This ocean has been conveniently referred to as the 'Tethys I' (Dewey et al., 1973) or 'Paleotethys' (Laubscher and Bernoulli, in press) to distinguish it from its Mesozoic and Cenozoic successors.

The central domains of this wedge-shaped ocean should have been underlain by an oceanic crust. 


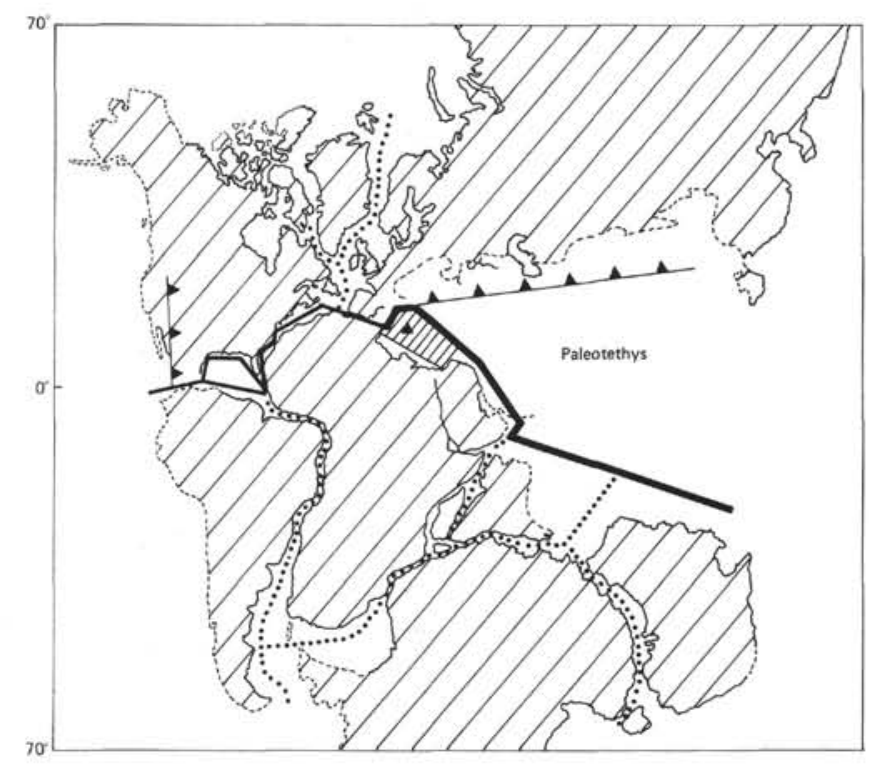

Figure 1. Reassembly of the principal continental masses in the Triassic, about $220 \pm 20$ m.y.B.P., after Smith et al. (1973). The heavy black line indicates the eastwest-oriented Mesozoic breakup of Pangaea; barbed lines approximate locations of Mesozoic subduction zones and dotted lines show the Cretaceous-Tertiary spreading center. The closely hatched area shows the eastern Mediterranean as a possible relic of Paleotethys, and the triangle shows the area of the Mesozoic triple point between the Eurasian, African, and Paleotethys plates.

Permo-Triassic ophiolites are the evidence we seek to confirm the plate-tectonic postulate. Our inability to recognize such ophiolites in the Tethyan mountain belt has led some to doubt the very existence of the Paleotethys (e.g., Meyerhoff and Eremenko, 1976). However, pelagic sediments of Triassic age are known from eastern Europe (Eastern Alps, Carpathians) and the central Mediterranean area (Apennines, Dinarides, Hellenides, Turkey). These sediments are often associated with alkaline volcanics and were deposited in relatively narrow elongated basins which are interpreted as the result of early rifting preceding the opening of the Jurassic Tethys (Scandone, 1975). Obviously these deeper marine seaways were connected with a larger oceanic area to the east. We believe that the oceanic crust and much of the continental crust of the Permo-Triassic Ocean were carried down to the mantle by plate-subduction under the southern margin of the southeastern European Platform. The existence of the Paleotethys can only be identified in a consuming plate-margin south of the Permo-Triassic Eurasian continent.

A consuming plate-margin may be delineated by its proximity to a belt of andesite-volcanism. Triassic and Jurassic volcanism can be traced from Dobrogea to Crimea to Caucasus (Dewey et al., 1973). Triassic flysch and submarine volcanic deposits have also been recognized in these regions. These rocks were de- formed during the "Cimmerian" orogeny (Nalivkin, 1973). We might thus place the northern margin of the Paleotethys along the Dobrogea-Crimea-Caucasus trend (Figure 2).

The southern margin of the Paleotethys (or the northern edge of Africa-Arabian continents) should be sought in the Middle East. A zone of ophiolite melange extended from Cyprus to southern Turkey, to Zagros in Iran, to Oman and thence to Afghan (Gansser, 1974). Yet like the Alpine ophiolites, the melanges include only rocks of Jurassic and Cretaceous age, but no Permo-Triassic ocean-floor fragments. The northern margin of the Triassic African continent should be present along the zones of Cimmerian deformation north of the Tethyan ophiolite belt. This Cimmerian suture (Figure 2) is now largely buried under the Black Sea, the post-orogenic basins of the Great Caucasus, and under the homocline (of Jurassic to Tertiary sediments) of the Kopet Dagh Range. Only here and there is a window present to permit one to look in at the "old scar." One of us (KJH) visited outcrops of ultramafic rocks, which occur as lenticular bodies in Carboniferous slates near Mashad southwest of the Kopet Dagh front in Iran. These rocks could well be melange blocks of fragmented Permo-Triassic sea floor. A melange zone including blocks from the Paleotethys is present in Afghanistan (Stöcklin, personal communication) and can be traced eastward through the north of the Pamir to the Tangula range in the north of the Tibet Plateau (Chang and Zhen, 1973) and thence southward to Indochina. This megasuture of Gondwana and Eurasia has been referred to as the Old Cimmerian in Europe and Indosinian in Asia (Figure 2). It seems difficult to contemplate that the broad expanse of a wedge-shaped ocean between Gondwana and Eurasia should have completely plunged to obscurity along this subduction zone. Yet there is no alternative if we are to accept the concept of a Triassic Pangea.

\section{TETHYS}

Fragmentation of the Pangea began in the middle to late Triassic. Subsidence created a number of "aborted oceans" within the Alpine realm, where submarine basalts, pelagic limestones, and flysch-like sediments accumulated. But most of these were stillborn embryos which never had a chance to develop into an ocean basin. The major reorganization of the continents and oceans started in Early Jurassic when the Pangea was split into a northern and a southern continent. The Central Atlantic was born where Africa was torn apart from North America and Europe (Pitman and Talwani, 1972). Opening of this part of the Atlantic obviously implies translational movements between Africa and Eurasia (Smith, 1971; Hsü 1971; Dewey et al., 1973). This movement is roughly coeval with the formation of oceanic crust in the LigurianPiedmont ophiolite zone as indicated by radiometric dating and the approximate age of the oldest overlying 


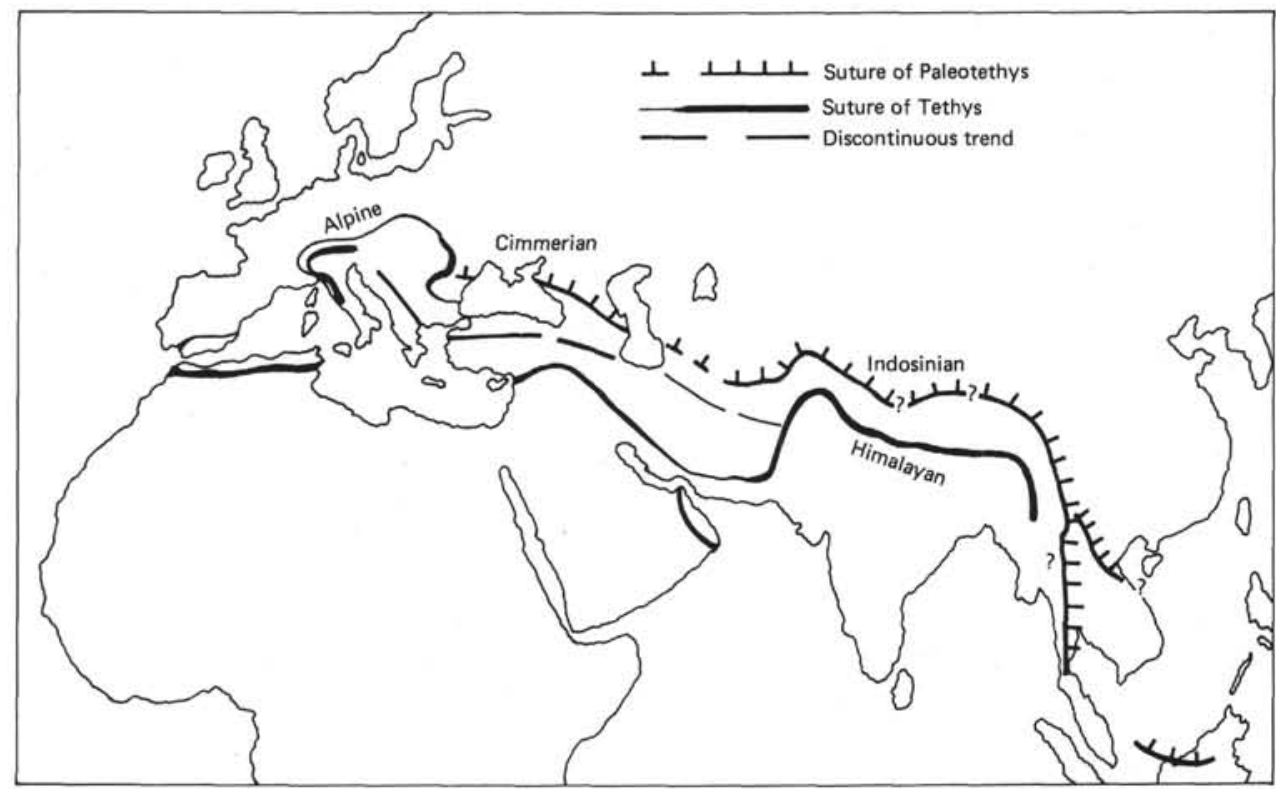

Figure 2. Location of two suture zones. The Paleotethys was eliminated by subduction along the Cimmerian-Indosinian suture zone. The Tethys s.s. disappeared through subduction and collision along the Alpine-Himalaya suture zone. The suture zones are defined by subduction tectonics and ophiolitic melanges. There are numerous uncertainties concerning the location of the Paleotethys suture where it is covered by Jurassic and younger post-orogenic sediments in the Soviet Union and in Tibet.

sediments (Decandia and Elter, 1972). A Jurassic age has also been established for some of the ophiolites in the eastern Mediterranean area (Hynes et al., 1972). Kinematic considerations then require essentially transcurrent movements, or a transform fault, with minor rifting only from Iberia to the Apennines. This seems to have been located in the Mauretanian-Massylian flysch trough. The marginal areas bordering this trough were pelagic in places from the Sinemurian onwards, although no ophiolites are known. The close similarities of its Early Cretaceous flysch sequence with similar and coeval flysch sequence of Sicily, of the Apennines (see Figure 3), of the northeastern central Atlantic and of the Canary Islands support this interpretation (see Laubscher and Bernoulli, in press).

East of Corso-Sardinia, the plate boundary swung to the north parallel to a true ridge segment where the ophiolites of the Liguria-Pennine trough accreted. The margins of this trough, particularly the southeastern segments, display a paleotectonic and sedimentary evolution which closely parallels that of passive Atlantic-type continental margins (Figure 4). Early Jurassic synsedimentary normal faulting was widespread on the northern and southern continental margins and was followed by submergence of many of the former shallow-water platforms which resulted in pelagic conditions prevailing over large areas. (Bernoulli and Jenkyns, 1974).

The ophiolites are somewhat less common in the Eastern Alps (Glockner facies in the Tauern window, Tollmann, 1975), but reappear as impressive masses in the Dinarides and Hellenides. It is not certain if there had been more than two ocean troughs separated by intervening microcontinents. We prefer a simple interpretation of a central Tethys, occupying what is now known as the Almopias subzone of the Vardar zone from which issued the great ophiolite nappes now lying far to the southwest (Bernoulli and Laubscher, 1972).

There are two or three zones of Mesozoic ophiolites in Anatolia and they may or may not originally have formed one central Tethys. An additional JurassicCretaceous spreading center was probably present in the eastern Mediterranean (Monod et al., 1974). The Ionian and Levantine basins may owe their origin to this episode of sea floor spreading (Hsü, in press) and the Troodos Massif on Cyprus probably represents an uplifted fragment of the Mesozoic ocean (Moores and Vine, 1971). The Iranian and Afghan ophiolites, like those of Anatolia also occur in two tectonically separate belts (Gansser, 1974). Farther east, the Tethys ocean should be represented by the ophiolites of the Indus Suture zone, north of the Himalaya main range.

The ophiolites of Jurassic and Cretaceous age were emplaced in basins between Eurasia or between the microcontinents and Africa. It is convenient to refer to those Mediterranean Ocean basins as Tethys, s.s. (Laubscher and Bernoulli, in press).

The creation of the Tethys in the west was accompanied by the destruction of the Paleotethys in the east along the consuming plate margin discussed previously. This suture of Paleotethys extends from Dobrogea, to Crimea, to northern Caucasus, to the Kopet Dagh of northeastern Iran, and thence through the "dark and unknown" interior of southwest Asia and surfaces again in Yunan (China), Indochina, and Indonesia (Figure 2). 


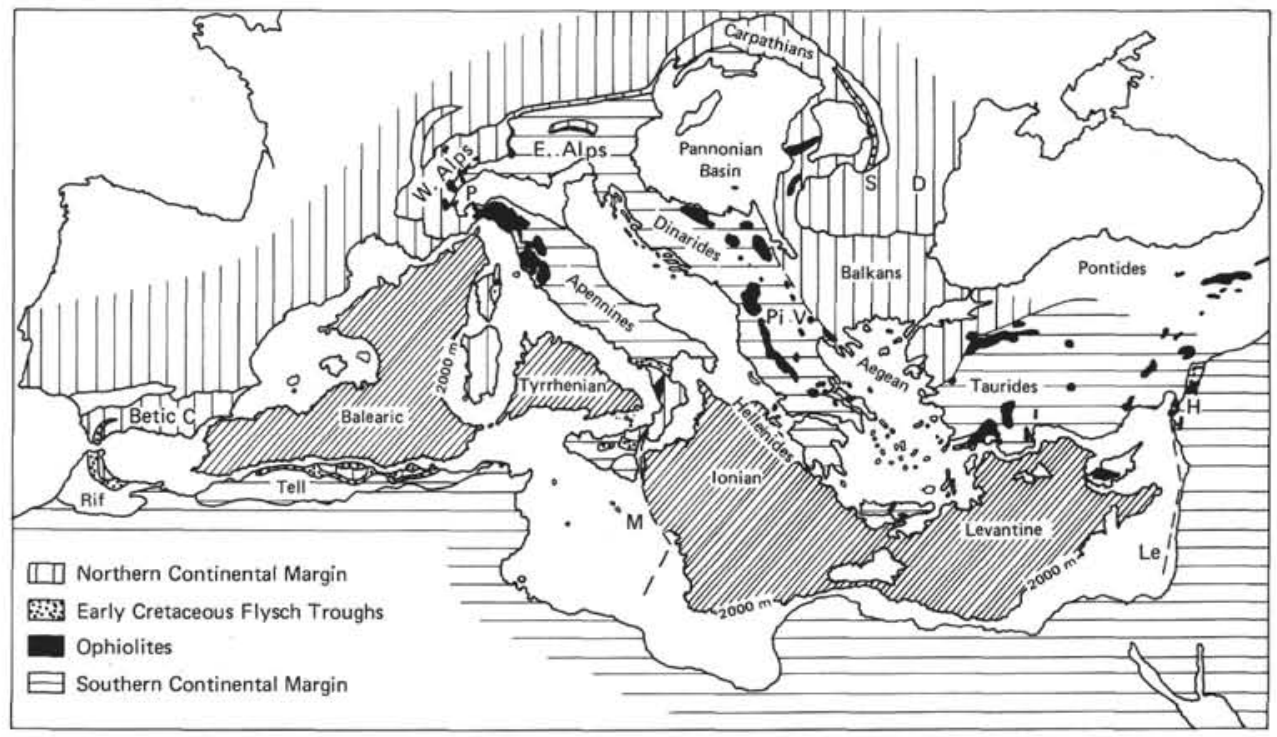

Figure 3. Occurrences of Tethyan ophiolites and associated oceanic sediments and interpreted extent of the northern and southern continental margins of the oceanic Tethys. Abbreviations for localities are: A. Antalya Nappes, D. Dobrogea, H. Hatay, I. Isparta, L. Ligurian ophiolites, Le. Levantine escarpment, M. Malta escarpment, P. Pennine (Piemont) ophiolites, Pi. Pindos, S. Sinaia Flysch, T. Troodos, V. Vardar Zone. (Figure after Laubscher and Bernoulli, in press).

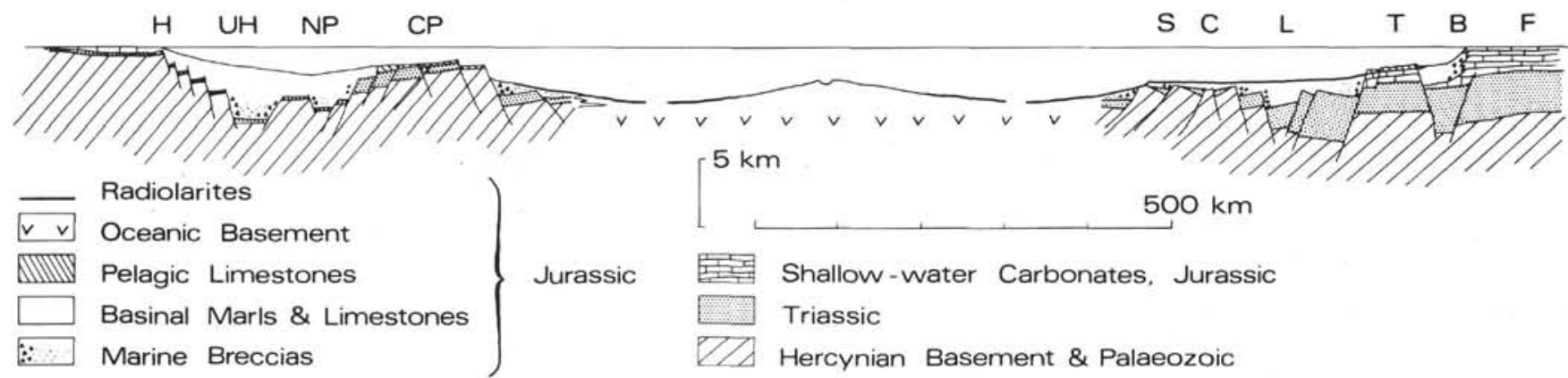

Figure 4. Palinspastic section through the Liguria-Piemont ocean in the Late Jurassic (Kimmeridgian). The main features are: 1. Thick "Alpine" shallow-water sediments in the Triassic of the Central Pennine realm on the northern continental margin. 2. An Early Jurassic phase of block-faulting in the embryonic continental margins (documented by marine breccia formations). 3. The onlap of pelagic deep-sea sediments over the deeply submerged continental margins following the initial phase of block-faulting. 4. The development of Bahamian-type carbonate platforms along the southern continental margin with adjacent troughs with pelagic and turbiditic carbonate sedimentation. 5. The development of the oceanic Tethys (documented by the ophiolite suite). Abbreviations: H. Helvetic, UH. Ultrahelvetic, NP. North Pennine, CP. Central Pennine, PP. "Prépiémontais," S. Sesia Zone, C. Canavese Zone, L. Lombardian Zone, T. Trento Zone, B. Belluno Zone, F. Friuli Zone. (Figure after Laubscher and Bernoulli, in press).

The grand eastward movement of Africa during Jurassic and Early Cretaceous is reminiscent of a military maneuver of "pincer encirclement." Microcontinents like sentries were detached forward to meet Eurasia along the Cimmerian front, leaving at their wake the Ligurian, the Vardar, the Tauride, the Zagros, and the Oman ophiolite troughs, as well as the East Mediterranean. The main mass followed and it was joined, or sutured, with the "advanced guards" during the Late Cretaceous and Tertiary along the ophiolite belt (Figure 3). Trapped in the pocket by this encirclement was the ancestral Eastern Mediterranean.

\section{ALPINE OROGENY}

We accept as our basic postulate the kinematic analysis of the relative movement between Europe and Africa on the basis of interpretation of sea floor magnetic lineations (Pitman and Talwani, 1972). According to this model Africa had moved by about 2000 $\mathrm{km}$ sinistrally with respect to Europe in response to the 
opening of the Central Atlantic. The movement then became dextral when the North Atlantic began to spread apart. Whereas the sinistral movement was accompanied by the birth of Tethys, the dextral movement led to her destruction. There is indeed excellent evidence in the geologic record for this dextral movement and closure of the Alpine System during the Late Cretaceous and Cenozoic. But there is some question about the exact time of the change. Interpretations of magnetic lineations in the Atlantic suggest that the dextral movement started about 80 m.y. ago, during the Santonian. From that time to the present about $1000 \mathrm{~km}$ dextral movement, associated with hundreds of kilometers of northward advance, is registered (Pitman and Talwani, 1972; Dewey et al., 1973).

However, the geological record indicates that the elimination of some eastern European ophiolite basins may have started in Early Cretaceous or even Late Jurassic (Aubouin, 1973); the deformation was probably related to local subductions during the sinistral phase of the movement of Africa. With the change to a dextral movement, Europe approached toward Africa, continuing from Late Cretaceous to latest Eocene until the Tethys ocean (except perhaps for the eastern Mediterranean) was completely consumed. Flysch sedimentation was widespread as orogenic movements proceeded and finally culminated in a complete continent-continent collision at the end of the Eocene. After the Tethys ocean and its margins were largely consumed by subduction, a series of new basins made their appearance, discordantly superposed on the orogenic zones. Those of them still under water constitute much of the present Mediterranean.

\section{MEDITERRANEAN}

Suess (1901) considered the Mediterranean a relic of the Tethys. Argand (1924), on the other hand, envisioned a complete elimination of the Tethys by the Alpine Orogeny. He postulated the genesis of the present Mediterranean basins during a major extensional phase in late Oligocene or early Miocene. We take an intermediate position. Whereas the Levantine and Ionian basins may represent relics of Tethys, the Balearic, Tyrrhenian, and Aegean basins are certainly Cenozoic creations. This difference in age is reflected in the very low and very high heat-flow values obtained from the eastern and the western basins, respectively (Erickson, this volume).

Of the three Cenozoic basins, the Balearic is the oldest dating back to earliest Miocene or latest Oligocene (Site 372 Report, this volume). The Tyrrhenian Basin is intermediate in age, and was formed largely prior to the Messinian salinity crisis. The Aegean Basin is the youngest, and there has been considerable Quaternary subsidence. The Balearic Abyssal Plain is underlain by an oceanic crust, but continental basement underlies large parts of the Aegean Sea. The Tyrrhenian Basin is again intermediate: a thin crust under the center of basin is probably oceanic, yet sialic basement rocks have also been dredged from a non- magnetic seamount within the abyssal plain province (see review by Hsü, in press).

Two schools of thought dominated the thinking on the genesis of the Mediterranean. Argand (1924) first advanced the idea that these basins are rifted types, produced by the rotation of micro-continents following the climax of Alpine orogeny. There is considerable new evidence for the origin of the Balearic Basin through the rotation of Corsica and Sardinia (see review by Hsü, in press). Meanwhile, the Tyrrhenian and the Aegean basins have been compared to marginal basins of the Pacific, which were formed by seafloor spreading behind island arcs (Boccaletti et al., 1972; Papazachos and Comninakis, 1971). An apparently opposing school played variations on the theme of oceanization (e.g. van Bemmelen, 1969; Laubscher, 1975). Laubscher and Bernoulli (in press) referred to the Mediterranean basins as post-orogenic collapse basins.

Recall that the sea-floor spreading model assumes the emplacement of basalt dike-swarms into a preexisting crust (Vine and Matthews, 1963). A sheeted dike complex has indeed formed a part of the Troodos Massif of Cyprus (Moores and Vine, 1971). Note that dike swarms intruding continental crust, are not uncommon. It is not improbable that dikes of oceanic tholeiites could be emplaced into pre-existing sialic crust, with a comparable spacing to that of the sheeted dike complex of Troodos. The subsidence of the Tertiary Mediterranean basins was caused by extension of the crust. We envision that a former continental crust was broken into a series of crustal slivers, which become septae between basalt dike-swarms. A sheeted dike complex may extend so far laterally that, it forms the crust of a rifted basin, with a composition and thickness similar to that of typical oceanic crust. In addition, the average composition of the crust may be "basified" through the emplacement of linear bodies of mantle-derived serpentized periodotite into fracturezones, in the fashion suggested by Bonatti and Honnorez (1976). We might then refer to the tectonic process as "oceanization," or as "rifting accompanying rotation of micro-continents," or as "seafloor spreading behind island arcs." So it seems that the actual difference between "oceanization" and "marginal basin" or that between "founderers" and "rifters" may not be so irreconcilable as the semantic contrast suggests.

\section{MEDITERRANEAN DURING AND AFTER THE LATE MIOCENE SALINITY CRISIS}

Despite the manifold opinions on the genesis of the Mediterranean, the various tectonic approaches have led to a consensus that the Mediterranean basins as we know them today were largely in existence when the Messinian salinity crisis began. Even if we follow the extreme postulate of Argand (1924), who proposed the total destruction of the Tethys by the Alpine orogeny, we must admit that the Mediterranean area was broken up and changed into a number of deep basins 
during the early and middle Miocene. We have no evidence that the Mediterranean region was a broad shelf sea similar to the Baltic during the late Miocene (or, for that matter, any time during the Tertiary), nor are the arguments convincing that the Mediterranean basins suddenly collapsed after the Messinian salinity crisis. The recovery of deep-water hemipelagic sediments directly above and below the Messinian evaporites during Leg $42 \mathrm{~A}$ has confirmed our view that the Mediterranean basins (except perhaps the Aegean) are not Pliocene-Quaternary creations. Large parts of the Mediterranean did subside during the PlioceneQuaternary. As the creation of the Tyrrhenian and Aegean basins were relatively recent events, continued tectonic subsidence there during the Pliocene-Quaternary is not unexpected. Elsewhere, however, the subsidence could be explained as an isostatic adjustment, if we accept the interpretation that the desiccated Mediterranean was suddenly drowned at the beginning of the Pliocene (Hsü et al., 1972; Ryan, 1976).

\section{SUMMARY}

We have attempted to present a broad outline of the evolution of the Alpine-Mediterranean system. We accept the postulate of the existence of a Pangea and a Panthalassa during the Triassic, and the implication of a wedge-shaped Paleotethys between Eurasia and the southern continents. We postulate that Paleotethys was totally eliminated along a consuming plate-margin, now represented by the "Cimmerian" and "Indosinian" orogenic belts. We agree that the ophiolites of the Alpine-Himalayan trend are uplifted fragments of the Tethys, which was born when Africa moved eastward, or sinistrally, with respect to Europe, in response to the seafloor spreading in the Central Atlantic. We believe that this Tethys was largely eliminated by the Alpine Orogeny during the Cretaceous and early Tertiary, when Europe moved eastward, or dextrally, with respect to Africa, in response to the sea floor spreading of the North Atlantic. Only the Levantine and Ionian basins are possible relics of the Tethys. We further maintain that the Western Mediterranean and the Aegean basins were formed in the Tertiary after the climax of the Alpine Orogeny, and that crustal extension and submarine volcanism played major roles in their genesis. The basins, except perhaps the Aegean, assumed approximately their present extent when the Messinian salinity crisis started. However, the paleogeography has undergone significant changes since the Messinian. Marginal areas of deep basins were severely deformed and the evaporite basins of Sicily, Calabria, the Apennines, the Tellian Atlas, the Ionian Islands, of Crete, Cyprus, etc. were uplifted and emerged during the Pliocene-Quaternary. At the same time the Tyrrhenian and Aegean basins continued to subside in response to back-arc tectonic activity. Finally, there was widespread isostatic subsidence in response to the drowning of previously desiccated deep basins.

\section{REFERENCES}

Aubouin, J., 1973. Des tectoniques superposées et de leur signification par rapport aux modèles géophysiques: l'exemple des Dinarides, paléotectonique, tarditectonique, néotectonique: Bull. Soc géol. France 15, 426-460.

Argand, E., 1924. La tectonique de l'Asie: Third Congr. géol. Intern., Bruxelles, Compt. Rend., p. 171-372.

Bernoulli, D. and Jenkyns, J. C., 1974. Alpine, Mediterranean, and Central Atlantic Mesozoic facies in relation to the early evolution of the Tethys. In Modern and ancient geosynclinal sedimentation: Dott, R. H. Jr., and Shaver, R. H. (Eds.), SEPM Spec. Publ. 1g, p. 129-160.

Bernoulli, D. and Laubscher, H., 1972. The Palinspastic problem of the Hellenides: Enclog. Geol. Helv., v. 65, p. 107-118.

Boccaletti, M., Elter, P., and Guazzone. G. 1971. Plate tectonic models for the development of the western Alps and northern Apennines: Nature, Phys. Sci., v. 49, p. 108-111.

Bonatti, E. and Honnorez, J., 1976. Sections of the Earth's crust in the Equatorial Atlantic: J. Geophys. Res., v. 81, p. 4104-4116.

Bullard, E. C., Everett, J. E., and Smith, A. G., 1965. The fit of the continents around the Atlantic: Phil. Trans. Roy. Soc. London, Sec. A, v. 258, p. 41-51.

Carey, S. W., 1958. A tectonic approach to continental driftA Symposium (S. W. Carey, Convener): Univ. Tasmania, Hobart, Australia, p. 177-355.

Chang, C. and Zhen, X., 1973. The characteristics of the geologic structure of the Mount Jolmo Lungma of southern Tibet of China and the discussion of the formation of the E-W mountain ranges of the Chinghai-Tibet Plateau: Sci. Sinica, v. 2.

Decandia, F. A. and Elter, P., 1972. La "zona" ofiolitifera del Bracco nel Settore compresso fra Levanto e la Val Graveglia, (Apennino ligure): Mem. Soc. Geol. Ital., v. 11, p. $503-530$.

Dewey, J. F., Pitman, W. C., Ryan, W. B. F., and Bonnin, J., 1973. Plate tectonics and the evolution of the Alpine system: Geol. Soc. Am. Bull., v. 84, p. 3137-3150.

Du Toit, A. L., 1937. Our wandering continents: Edinburgh (Oliver and Bound).

Gansser, A., 1974. The ophiolitic mélange, a world-wide problem on Tethyan examples: Eclo. Geol. Helv., v. 67, p. 479-507.

Hsü, K. J., 1971. Origin of the Alps and western Mediterranean: Nature, v. 233 , p. $44-48$

Hsü, K. J., in press. Tectonic evolution of the Mediterranean Basins. In The Ocean Basins and Margins. IV Mediterranean: Nairn, A. E. M., Stehli, F. G., and Kanes, W., (Eds.), New York, (Plenum: Publ. Corp.).

Hsü, K. J., Cita, M. B., and Ryan, W. B. F., 1972. The origin of the Mediterranean Evaporites. In Ryan, W. B. F., Hsü, K.J., et al., Initial Reports of the Deep Sea Drilling Project, Volume 13: p. 1023-1231, Washington, D.C. (U.S. Government Printing Office).

Hynes, A. J., Nisbet, E. G., Smith, A. G., Welland, M. J. P., and Rex, D. C., 1972. Spreading and emplacement ages of some ophiolite in the Othris region, eastern central Greece: Z.Dtsch.Geol.Ges., v. 123, p. 445-468.

Laubscher, H. P., 1975. Plate boundaries and microplates in Alpine history: Am. J. Sci. v. 275, p. 865-876.

Laubscher, $\mathrm{H}$. and Bernoulli, D, in press. Mediterranean and Tethys. In The Ocean Basins and Margins. IV Mediterra- 
nean: Nairn, A. E. M., Stehli, F. G., and Kanes, W., (Eds.). New York, Plenum Publ. Corp.

Meyerhoff, A. A. and Eremenko, N. A., 1976. Eurasian plate boundaries in USSR: Am. Assoc. Petrol. Geol. Bull., v. 60, p. 697.

Monod, O., Marcoux, J., Poisson, A., and Dumont, J. F., 1974. Le domaine d'Antalya, témoin de la fracturation de la plate-forme africaine au cours du Trias: Bull. Soc. Géol. France, v. 16, p. 116-127.

Moores, E. M. and Vine, F. J., 1971. The Troodos Massif, Cyprus, and other ophiolites as ocean crusts; evaluation and implications: Phil. Trans. Roy. Soc. London, Sec. A, v. 268 , p. $443-446$.

Nalivkin, D. V., 1973. Geology of the U.S.S.R.: Univ. Toronto Press, $855 \mathrm{p}$.

Neumayr, M., 1885. Klimatische Zonen Während der Juraund Kreisdezeit: Denkschr. Kais. Akad. Wiss. Wien, v. 47 , p. $1-34$.

Papazachos, B. C. and Comninakis, P. E., 1971. Geophysical and tectonic features of the Aegean Arc: J. Geophys. Res., v. 76, p. $8523-8533$.

Pitman, W. C. and Talwani, M., 1972. Sea-floor spreading in the North Atlantic, Geol. Soc. Am. Bull., v. 83, p. 619-646.

Ryan, W. B. F., 1976. Quantitative evaluation of the depth of the western Mediterranean, before, during, and after the late Miocene salinity-crisis: Sedimentology, v. 23, p. 791813.

Scandone, P., 1975. Triassic seaways and the Jurassic Tethys Ocean in the central Mediterranean area: Nature, v. 256, p. $117-118$.

Smith, A. G., 1971. Alpine deformation and the oceanic areas of the Tethys, Mediterranean and Atlantic: Geol. Soc. Am. Bull., v. 82, p. 2039-2070.

Smith, A. G., Briden, J. C., and Dewey, G. E., 1973. Phanerozoic world maps: Paleontology, Spec. Paper 12, p. $1-42$.

Suess, E., 1893. Are great oceans depth permanent?: Nat. Sci., v. 2, p. $180-187$. 1901. "Das Antlith der Erde." 3, Bd., Wien.

Tollmann, A., 1975. Ozeanische Kruste im Pennin des Tauernfensters und die Neugliederung des Deckenbaues der Hohen Tauern: N.Jb.Geol. Paläont. Abh., v. 148, p. 286-319.

van Bemmelen, R. W., 1969. Origin of the western Mediterranean Sea:. Verhandl. Kon. Ned. Geol. Mijnbouwk. Gen., v. 26, p. 13-52. SW Vine, F. J. and Matthews, D. H., 1963. Magnetic anomalies over oceanic ridges: Nature, v. 199 , p. $947-949$.

Wegener, A., 1929. Die Entstehung der Kontinente und Ozeane, Vieweg, Braunschweig. 